\title{
PENGARUH MODEL PEMECAHAN MASALAH DAN KREATIVITAS TERHADAP HASIL BELAJAR IPA MATERI SISTEM PENCERNAAN MAKANAN MANUSIA SISWA DI SDN 060856 MEDAN
}

\author{
Restar Tarigan \\ Surel: tariganrestar@yahoo.com
}

\begin{abstract}
This study aimed to analyze The influence of science learning outcomes of students. This study is a quasi experimental research(quasi experiment). This population is the class V SD 060856 Medan. The sample in this study selected by purposive random sampling as much as two grades. The instrument used consisted of: science achievement test and learning creativity questionnaire sheet. Data analysis was performed using ANOVA two lanes. The results of this study indicate that the learning outcomes of students that learned Science with problem solving learning model is significantly different and better than the students that learned by direct instruction learning. Students with high creativity indicates higher learning outcomes than students with low creativity. In this study shows there is an interaction between the learning model and the level of creativity in influencing student Science learning outcomes.
\end{abstract}

Keywords: Learning Outcomes, Creativity, Solution Of Problem

\begin{abstract}
ABSTRAK
Penelitian ini bertujuan untuk menganalisis pengaruh model pembelajaran terhadap hasil belajar IPA siswa. Penelitian ini merupakan penelitian eksperimen semu (quasi experiment). Populasi penelitian ini adalah siswa kelas V SD 060856 Medan. Sampel dalam penelitian ini dipilih secara purposive random sampling sebanyak dua kelas. Instrumen yang digunakan terdiri dari: tes hasil belajar IPA dan angket kreativitas belajar. Analisis data dilakukan dengan menggunakan ANAVA dua jalur. Hasil dari penelitian ini menunjukkan bahwa hasil belajar IPA siswa yang dibelajarkan dengan model pembelajaran pemecahan masalah berbeda secara signifikan dan lebih baik dibandingkan siswa yang dibelajarkan dengan pembelajaran langsung. Siswa dengan kreativitas tinggi menunjukkan hasil belajar yang lebih tinggi dibanding siswa dengan kreativitas rendah. Terdapat Interaksi antara kedua model pembelajaran dan tingkat kreativitas dalam mempengaruhi hasil belajar IPA siswa.
\end{abstract}

Kata Kunci: Hasil Belajar, Kreativitas, Pemecahan Masalah

\begin{tabular}{lrlllr} 
PENDAHULUAN & & Sumber & Daya & Manusia & (SDM) \\
Pendidikan diartikan & sebagai & melalui kegiatan pengajaran. Di \\
usaha & sadar & untuk & dalam pendidikan terdapat suatu \\
menumbuhkembangkan & potensi & proses & belajar mengajar yang \\
\hline
\end{tabular}

Universitas Quality Brastagi 
merupakan inti dari proses pendidikan di sekolah. Dalam belajar mengajar ada interaksi atau pelajaran yang diajarkan oleh guru. Guru mengajar dengan merangsang, membimbing siswa dan mengarahkan siswa mempelajari bahan pelajaran sesuai dengan tujuan. Dalam pembelajaran, khususnya pembelajaran IPA di SD tidaklah cukup hanya diberikan sejumlah besar pengetahuan kepada para siswa saja, akan tetapi para siswa perlu memiliki keterampilan untuk membuat pilihan-pilihan dan menyelesaikan berbagai masalah dengan menggunakan penalaran yang logis dalam pembelajaran IPA. Oleh karena itu, setiap guru khususnya guru SD yang mengelola pembelajaran IPA perlu memahami maksud dari memecahkan masalah IPA. Selain itu setiap guru juga harus melatih keterampilannya dalam membantu siswa belajar memecahkan masalah IPA.

Melalui model pemecahan masalah, siswa dapat memiliki keterampilan memecahkan masalah (problem solving). Keterampilan menyelesaikan masalah tersebut akan dicapai siswa jika dalam pembelajaran guru mengkondisikan siswa untuk dapat mengkontruksi pengetahuannya dan memfasilitasi siswa untuk melakukan aktivitas belajar yang melibatkan pemecahan masalah dalam pembelajaran IPA. Untuk mengatasi masalah dalam pembelajaran IPA siswa harus belajar bagaimana mengelola masalah yang dihadapinya. Dalam mengelola masalah dibutuhkan kemampuan berpikir secara kritis, sistematis, logis, dan kreatif. Pada pembelajaran IPA di SDN 060856 Medan ditemukan masalah yang sama dijumpai pada siswa yakni lemahnya siswa dalam menyelesaikan pemecahan masalah dalam proses pembelajaran IPA sehingga hal ini memberikan dampak akan rendahnya hasil belajar siswa dengan nilai rata-rata 65 yang tidak mencapai Kriteria Ketuntasan Minimal (KKM) yakni 70. Oleh karena itu penting adanya model pemecahan masalah dalam pembelajaran IPA.

Anderson

(2011), mengemukakan bahwa pembelajaran dengan menekankan pendekatan pemecahan masalah dapat memberikan keberhasilan bagi para siswa dalam menguji pengetahuan yang dimiliki dengan mempromosikan kemampuan setiap siswa untuk mengenali dan mengembangkan kemampuan pemecahan masalah mereka dalam pembelajaran IPA, dengan pendekatan pemecahan masalah dalam konteksnya siswa dapat menghormati pentingnya konten konsep pengetahuan dan aplikasinya ke keterampilan karir yang akan dibutuhkan siswa itu sendiri. Hasil penelitian Williamson (2002), juga 
mengemukakan bahwa hasil belajar siswa yang dibelajarkan dengan pendekatan pemecahan masalah dalam kelompok lebih baik dibandingkan dengan metode ceramah (konvensional).

Pada penelitian yang relevan dilakukan oleh Rosmalinda, dkk (2013), menunjukkan bahwa petunjuk praktikum yang terdapat dalam bahan ajar IPA SD kelas $\mathrm{V}$ yang dikaji memiliki karakteristik bahan yang digunakan mudah diperoleh namun alat yang digunakan sulit diperoleh serta komponen petunjuk praktikum tidak lengkap. Berdasarkan hasil uji keterlaksanaan, respons siswa, dan penilaian guru, kualitas petunjuk praktikum pada topik Energi dan perubahannya yang dikembangkan termasuk kategori sangat baik, Penuntun praktikum model berbasis proyek tidak lebih efektif daripada model penemuan. Salah satu penyebabnya yaitu masih asingnya model berbasis pada praktikum di sekolah sehingga kreatifitas siswa dalam menerapkan model berbasis proyek belum maksimal.

Guru harus berusaha menanamkan dan menumbuhkan kreativitas anak didik. Setiap orang memiliki kreativitas dan kreativitas itu dapat dikembangkan. Menurut Sipayung (2011), siswa yang memilki kreativitas tinggi dalam belajar maka hasil belajar juga tinggi, karena itu kreativitas menjadi bagian penting dalam wacana peningkatan mutu pembelajaran. Hingga kini kreativitas telah diterima baik sebagai kompetisi yang melekat pada proses dan hasil belajar.

Untuk mencapai tujuan pembelajaran dan kreativitas maka guru melakukan inovasi pembelajaran untuk menghasilkan lulusan yang berkualitas. Salah satu pendekatan dalam pembelajaran untuk dapat mewujudkan siswa dapat berpikir kreatif yaitu dengan model pembelajaran pemecahan masalah. Model pemecahan masalah merupakan sebagai proses pendekatan pembelajaran yang menuntut siswa untuk menyelesaikan masalah, dimana problem yang harus diselesaikan tersebut bisa dibuat-buat sendiri oleh guru, dapat pula masalah yang sudah dialami siswa dan ada kalanya fakta nyata yang ada di lingkungan kemudian dipecahkan dalam pembelajaran di kelas, dengan berbagai cara teknik.

\section{METODE PENELITIAN}

Penelitian ini dilaksanakan di SDN 060856 Medan, Jalan Gereja No. 2 Medan. Penelitian ini dilakukan pada semester genap tahun pembelajaran 2016-2017 mulai bulan Januari 2017 sampai dengan bulan Maret 2017. Penelitian ini bersifat quasi experiment (eksperimen semu). Pada penelitian ini, ada dua kelompok kelas yang mendapat perlakuan yang 
berbeda. Kelompok kelas pertama dibelajarkan dengan model Pemecahan Masalah sebagai kelas eksperimen dan kelompok kelas kedua dibelajarkan dengan model pembelajaran Langsung. Skor kreativitas belajar digunakan untuk membedakan siswa yang memiliki kreativitas tinggi dan rendah.

Tabel 1. Kreativitas Pada Siswa

\begin{tabular}{|c|c|c|}
\hline Kreativitas & $\begin{array}{c}\text { Pemecahan } \\
\text { Masalah } \\
\text { (Kelas } \\
\text { Eksperimen) } \\
\left(\mathrm{A}_{1}\right)\end{array}$ & $\begin{array}{c}\text { Pembelajaran } \\
\text { Langsung } \\
\text { (Kelas } \\
\text { kontrol) } \\
\left(\mathrm{A}_{2}\right)\end{array}$ \\
\hline Tinggi $\left(\mathrm{B}_{1}\right)$ & $\mathrm{A}_{1} \mathrm{~B}_{1}$ & $\mathrm{~A}_{2} \mathrm{~B}_{1}$ \\
\hline $\begin{array}{c}\text { Rendah } \\
\left(\mathrm{B}_{2}\right)\end{array}$ & $\mathrm{A}_{1} \mathrm{~B}_{2}$ & $\mathrm{~A}_{2} \mathrm{~B}_{2}$ \\
\hline
\end{tabular}

Pada analisis penelitian ini yang digunakan adalah analisis secara deskriptif dan inferensial. Data yang terkumpul dianalisis dengan daftar distribusi frekuensi dan membuat histogram. Dari daftar frekuensi tersebut dihitung nilai rata-rata, simpangan baku.

Uji normalitas dimaksudkan untuk menentukan normal atau tidaknya distribusi data penelitian, artinya apakah penyebarannya dalam populasi bersifat normal. Untuk uji normalitas menggunakan uji Shapiro Wilk, data dikatakan berdistribusikan normal apabila nilai probabilitas signifikan (2-sisi) > taraf signifikan $5 \%$. Uji homogenitas bertujuan untuk mengetahui apakah penyebaran data dalam populasi bersifat homogen. Uji homogenitas dilakukan dengan uji-F factorial (factorial F-test), dinyatakan data bersifat homogen apabila nilai probabilitas signifikan (2-sisi) > taraf signifikan 0,05 .

Untuk menguji hipotesis penelitian digunakan teknik analisis varians (univariate analysis of variance).

a. $\mathrm{H}_{\mathrm{O}}: \mu \mathrm{A}_{1} \leq \mu \mathrm{A}_{2}$ $H_{a}: \mu A_{1}>\mu A_{2}$

b. $\mathrm{H}_{\mathrm{O}}: \mu \mathrm{B}_{1} \leq \mu \mathrm{B}_{2}$ $\mathrm{H}_{\mathrm{a}}: \mu \mathrm{B}_{1}>\mu \mathrm{B}_{2}$

c. $\mathrm{H}_{\mathrm{O}}: \mathrm{A}><\mathrm{B}=0$ $\mathrm{H}_{\mathrm{a}}: \mathrm{A}><\mathrm{B} \neq 0$

Keterangan:

a. Ho : $\mu \mathrm{A} 1 \leq \mu \mathrm{A} 2$ : Model pembelajaran pemecahan masalah mempengaruhi hasil belajar IPA siswa lebih rendah daripada model pembelajaran langsung.

Ha : $\mu \mathrm{A} 1>\mu \mathrm{A} 2:$ Model pembelajaran pemecahan masalah mempengaruhi hasil belajar siswa lebih baik daripada model pembelajaran langsung.

b. Ho : $\mu \mathrm{B} 1 \leq \mu \mathrm{B} 2$ : Tingkat kreativitas tinggi mempengaruhi hasil belajar IPA siswa lebih rendah dibanding kreativitas rendah.

Ha : $\mu \mathrm{B} 1>\mu \mathrm{B} 2$ : Tingkat kreativitas tinggi mempengaruhi hasil belajar IPA siswa lebih baik dibanding kreativitas rendah. 
c. $\mathrm{H}_{\mathrm{O}}: \mathrm{A}><\mathrm{B}=0$ : Tidak terdapat interaksi antara masing-masing model pembelajaran dengan tingkat kreativitas dalam mempengaruhi hasil belajar IPA siswa.

$\mathrm{H}_{\mathrm{a}}: \quad \mathrm{A}><\mathrm{B} \neq 0$ : Terdapat interaksi antara masing-masing model pembelajaran dengan tingkat kreativitas dalam mempengaruhi hasil belajar IPA siswa.

Kriteria Hipotesis : Probabilitas Sig. $<$ 0,05 maka $\mathrm{H}_{0}$ ditolak.

\section{HASIL DAN PEMBAHASAN}

Setelah data-data terkumpul dan dianalisis statistiknya, selanjutnya dilakukan uji hipotesis dengan teknik ANAVA Faktorial 2 x 2 dengan bantuan SPSS 22.0. Berdasarkan rincian tersebut maka akan diperinci pengujian hipotesis sebagai berikut:

a. Hipotesis Pertama

Pengujian hipotesis pertama yang berbunyi "Model pemecahan masalah mempengaruhi hasil belajar siswa lebih baik daripada model pembelajaran langsung”. Hipotesis statistiknya adalah:

Ho : $\mu \mathrm{A} 1 \leq \mu \mathrm{A} 2$

$\mathrm{Ha}: \mu \mathrm{A} 1>\mu \mathrm{A} 2$

Berdasarkan perhitungan anava faktorial $2 \times 2$ diperoleh $\mathrm{F}_{\text {hitung }}$ $=86,985$ sedangkan nilai $\mathrm{F}_{\text {tabel }}=$ 2,061 dan signifikansi 0,000 ternyata nilai $F_{\text {hitung }} 86,985>F_{\text {tabel }} 2,061$ dan nilai signifikansi $0,000<0,05$ sehingga pengujian hipotesis menolak Ho. Dengan demikian dapat ditarik kesimpulan bahwa hasil belajar IPA siswa yang dibelajarkan dengan model pemecahan masalah berbeda dengan hasil belajar IPA siswa yang dibelajarkan dengan model pembelajaran langsung.

Hal ini terlihat dari rata-rata hasil belajar IPA siswa yang dibelajarkan dengan model pemecahan masalah $(\bar{X}=80,667)$ lebih tinggi dibanding skor hasil belajar siswa yang dibelajarkan dengan model pembelajaran langsung $(\bar{X}=63,667)$. Berikut disajikan dalam bentuk histogram pengaruh model pembelajaran (pemecahan masalah dengan pembelajaran langsung) terhadap hasil belajar IPA siswa.

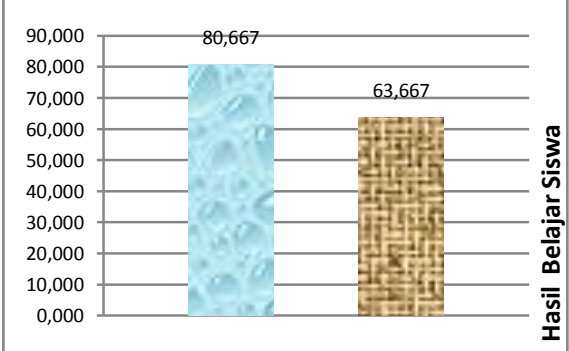

Gambar 1. Histogram Perbandingan Pengaruh Model Pembelajaran (Pemecahan Masalah Dan Pembelajaran Langsung) Terhadap Hasil Belajar IPA Siswa.

b. Hipotesis Kedua

Pengujian hipotesis kedua yang berbunyi: "Tingkat kreativitas tinggi mempengaruhi hasil belajar 
IPA siswa lebih baik dibanding kreativitas rendah" dengan hipotesis statistiknya:

$\mathrm{H}_{\mathrm{o}}: \mu \mathrm{B} 1 \leq \mu \mathrm{B} 2$

$\mathrm{H}_{\mathrm{a}}: \mu \mathrm{B} 1>\mu \mathrm{B} 2$

Berdasarkan perhitungan anava faktorial 2 x 2 pada Tabel diperoleh $\mathrm{F}_{\text {hitung }}=62,048$ sedangkan nilai $\mathrm{F}_{\text {tabel }}=2,061$ dan taraf signifikansi 0,05 ternyata nilai $F_{\text {hitung }}$ $62,048>F_{\text {tabel }} 2,061$ sehingga pengujian hipotesis menolak $\mathrm{H}_{0}$. Dengan demikian dapat ditarik kesimpulan bahwa hasil belajar IPA siswa yang memiliki kreativitas tinggi berbeda dengan hasil belajar siswa yang memiliki kreativitas rendah. Hal ini terlihat dari rata-rata nilai hasil belajar siswa yang memiliki kreativitas tinggi $\quad(\bar{X}=76,83)$ lebih tinggi dibanding rata-rata nilai hasil belajar siswa yang memiliki kreativitas rendah $(\bar{X}=62,11)$ atau berbeda sebesar $10 \%$.

Berikut disajikan dalam bentuk histogram pengaruh kreativitas belajar (tinggi dan rendah) terhadap hasil belajar IPA siswa.

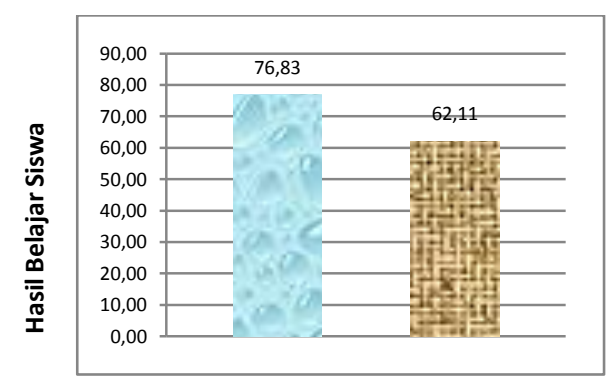

Gambar 2. Histogram perbandingan Kreativitas Belajar (tinggi-rendah) terhadap hasil belajar IPA siswa. c. Hipotesis Ketiga

Pengujian hipotesis kedua yang berbunyi: "Terdapat interaksi antara masing-masing model pembelajaran dengan kreativitas siswa dalam mempengaruhi hasil belajar IPA siswa" dengan hipotesis statistiknya:

Ho : $\mathrm{A}><\mathrm{B}=0$

Ha : $\mathrm{A}><\mathrm{B} \neq 0$

Berdasarkan perhitungan anava faktorial $2 \times 2$ pada Tabel 4.11 diperoleh $\mathrm{F}_{\text {hitung }}=4,692$ sedangkan nilai $\mathrm{F}_{\text {tabel }}=2,061$ untuk dk $(2 ; 59)$ dan taraf signifikansi $0,035<0,05$ ternyata nilai $F_{\text {hitung }} 4,692<F_{\text {tabel }}$ 2,061 sehingga pengujian hipotesis menolak $\mathrm{H}_{0}$. Hal ini juga dapat dilihat dari grafik yang ditampilkan berdasarkan rata-rata skor hasil belajar dari setiap kelompok penelitian berikut:

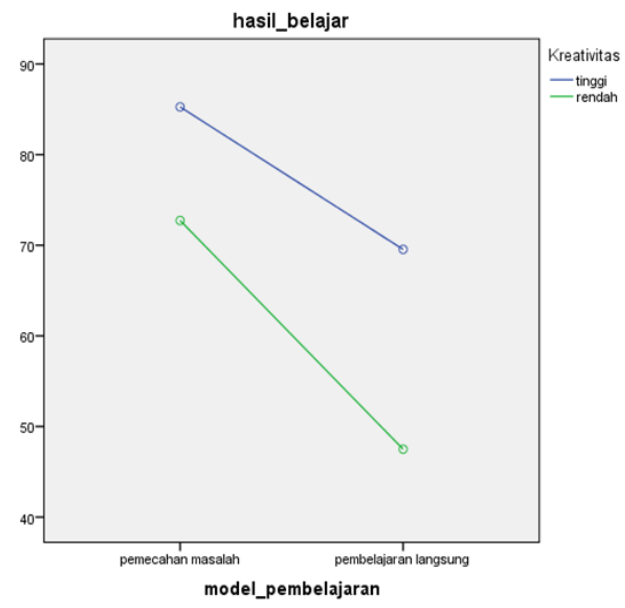

Gambar 3. Grafik interaksi masingmasing model pembelajaran dengan kreativitas belajar siswa dalam mempengaruhi hasil belajar IPA siswa. 
Dari grafik, terlihat bahwa garis yang dibentuk dari grafik skor membentuk garis yang tidak sejajar dan hampir berpotongan. Hal ini terjadi karena nilai hasil belajar IPA kelompok siswa yang dibelajarkan dengan model pemecahan masalah memberikan hasil yang berbeda pada tingkat kreativitas belajar siswa. Hal ini dapat dilihat dari hasil belajar IPA yang diperoleh siswa yang memiliki tingkat kreativitas tinggi hasilnya lebih baik atau lebih tinggi dibanding dengan siswa yang memiliki kreativitas rendah. Sedangkan nilai hasil belajar pada kelas kontrol dengan kreativitas tinggi dan kreativitas rendah mengalami kenaikan yang tidak signifikan seperti hal nya yang terjadi pada kelas eksperimen.

Dengan demikian, dapat disimpulkan bahwa terjadi efek interaksi yang signifikan antara model pembelajaran dan tingkat kreativitas belajar siswa terhadap hasil belajar siswa. Untuk mengetahui lebih lanjut tentang interaksi antara model pembelajaran dan kreativitas belajar siswa dilakukan uji lanjut untuk mengetahui rata-rata perbedaan hasil belajar setiap kelompok. Uji lanjut ini menggunakan Post Hoc Test dengan uji Scheffe yang hasilnya disajikan pada tabel berikut:
Tabel 2. Post Hoc Test dengan Uji Scheffe

\begin{tabular}{|l|c|c|c|c|}
\hline \multirow{2}{*}{$(\mathbf{I})$ interaksi } & \multirow{2}{*}{$(\mathbf{J})$ interaksi } & $\begin{array}{c}\text { Mean } \\
\text { Difference } \\
(\mathbf{I}-J)\end{array}$ & $\begin{array}{c}\text { Std. } \\
\text { Error }\end{array}$ & Sig. \\
\hline \multirow{3}{*}{ PM_Tinggi } & PM_Rendah & $12,536^{*}$ & 2,968 &, 001 \\
\cline { 2 - 5 } & PL_Tinggi & $15,718^{*}$ & 2,454 &, 000 \\
\cline { 2 - 5 } & PL_Rendah & $37,763^{*}$ & 3,302 &, 000 \\
\hline PM_Rendah & PL_Rendah & $25,227^{*}$ & 3,640 &, 000 \\
\hline PL_Tinggi & PL_Rendah & $22,045^{*}$ & 3,235 &, 000 \\
\hline
\end{tabular}

Perhitungan Scheffe Test digunakan untuk melihat ada tidaknya perbedaan hasil belajar tiap kelompok siswa. pengujian ini dilakukan dengan membandingkan hasil belajar siswa tiap-tiap kelompok. Kriteria pengujian yang dilakukan adalah:

1. Jika nilai sig. atau probabilitas < 0,05 maka ada perbedaan hasil belajar antara kedua kelompok.

2. Jika nilai sig. atau probabilitas $>0,05$ maka tidak ada perbedaan hasil belajar antara kedua kelompok

Analisis Tabel hasil uji lanjut atau Post Hoc Test dengan uji Scheffe menunjukkan bahwa ada perbedaan hasil belajar IPA yang signifikan antara kelompok siswa yang dibelajarkan dengan model pemecahan masalah dengan tingkat kreativitas tinggi dengan model pemecahan masalah dengan tingkat kreativitas rendah. (Mean Diff. = 12,536; sig. 0,001<0,05).

Selanjutnya, hasil perhitungan uji Scheffe menunjukkan bahwa ada perbedaan hasil belajar IPA yang 
signifikan antara kelompok siswa yang dibelajarkan dengan model pemecahan masalah dengan tingkat kreativitas tinggi dengan model pembelajaran langsung dengan tingkat kreativitas tinggi. (Mean Diff. =15,718; sig. $0,000<0,05)$.

Hasil perhitungan uji Scheffe menunjukkan bahwa ada perbedaan hasil belajar IPA yang signifikan antara kelompok siswa yang dibelajarkan dengan model pemecahan masalah dengan tingkat kreativitas tinggi dengan model pembelajaran langsung dengan tingkat kreativitas rendah. (Mean Diff. $=37,763$; sig. 0,000 <0,05).

Perhitungan uji Scheffe juga menunjukkan bahwa ada perbedaan hasil belajar IPA yang signifikan antara kelompok siswa yang dibelajarkan dengan model pemecahan masalah dengan tingkat kreativitas rendah dengan model pembelajaran langsung dengan tingkat kreativitas rendah. (Mean Diff. $=25,227$; sig. $0,000<0,05$ ).

Uji Scheffe juga menunjukkan bahwa tidak ada perbedaan hasil belajar IPA yang signifikan antara kelompok siswa yang dibelajarkan dengan model pembelajaran langsung dengan tingkat kreativitas tinggi dengan model pembelajaran langsung dengan tingkat kreativitas rendah. (Mean Diff. $=22,045$; sig. $0,00<$ $0,05)$.

\section{Pembahasan}

Berdasarkan analisis data tersebut, dapat disimpulkan bahwa terdapat interaksi antara model pemecahan masalah dengan kreativitas dalam mempengaruhi hasil belajar IPA siswa. Dengan demikian maka hipotesis penelitian yang berbunyi:

a. Model pembelajaran pemecahan masalah mempengaruhi hasil belajar IPA lebih baik daripada model pembelajaran langsung di SDN 060856 Medan, dapat diterima.

b. Tingkat kreativitas tinggi dapat mempengaruhi hasil belajar IPA siswa lebih baik dibanding kreativitas rendah, dapat diterima di SDN 060856 Medan.

c. Terdapat interaksi antara masingmasing model pembelajaran dengan tingkat kreativitas dalam mempengaruhi hasil belajar IPA siswa di SDN 060856 Medan, dapat diterima.

\section{SIMPULAN}

Berdasarkan hasil penelitian yang telah dikemukakan sebelumnya, maka dapat ditarik kesimpulan sebagai berikut : (1) Hasil belajar IPA siswa yang dibelajarkan dengan model pembelajaran pemecahan masalah lebih baik daripada hasil belajar IPA siswa yang dibelajarkan dengan model pembelajaran langsungdi SDN 060856 Medan, 
yaitu diperoleh rata-rata hasil belajar sebesar 80,667 lebih tinggi dibanding dengan model pembelajaran langsung sebesar 63,667. (2) Tingkat kreativitas tinggi mempengaruhi hasil belajar IPA siswa lebih baik dibanding kreativitas rendah, yaitu rata-rata hasil belajar siswa yang memiliki kreativitas tinggi 74,15 lebih tinggi dibanding rata-rata skor hasil belajar siswa yang memiliki kreativitas rendah 62,11. (3) Terdapat interaksi antara model pembelajaran pemecahan masalah dan model pembelajaran langsung dengan kreativitas siswa dalam mempengaruhi hasil belajar IPA siswa. Hal ini terjadi karena nilai hasil belajar IPA kelompok siswa yang dibelajarkan dengan model pembelajaran pemecahan masalah memberikan hasil yang berbeda pada tingkat kreativitas belajar siswa. Hal ini dapat dilihat dari hasil belajar IPA yang diperoleh siswa yang memiliki tingkat kreativitas tinggi hasilnya lebih baik atau lebih tinggi dibanding dengan siswa yang memiliki kreativitas rendah. Sedangkan nilai hasil belajar pada kelas kontrol dengan kreativitas tinggi dan kreativitas rendah mengalami kenaikan yang tidak signifikan seperti hal nya terjadi pada kelas eksperimen.

Hasil penelitian ini juga menunjukkan terdapat interaksi model pembelajaran dan tingkat kreativitas tinggi terhadap hasil belajar IPA.
Interaksi tersebut terindikasi dari siswa dengan tingkat kreativitas rendah dan dibelajarkan dengan model pembelajaran langsung, sedangkan bagi siswa dengan tingkat kreativitas tinggi dan dibelajarkan dengan model pembelajaran pemecahan masalah secara rata-rata lebih tinggi dibandingkan dengan menggunakan model pembelajaran langsung. Dengan demikian dapat dipahami bahwa model pembelajaran pemecahan masalah sesuai untuk siswa dengan tingkat kreativitas tinggi dan model pembelajaran langsung lebih efektif untuk membelajarkan siswa dengan tingkat kreativitas rendah.

Hasil penelitian juga menunjukkan bahwa untuk meningkatkan hasil belajar IPA dipengaruhi oleh model pembelajaran yang diterapkan oleh guru dan tingkat kreativitas siswa. Dalam hal ini antara guru dan siswa mempunyai peranan yang sama dan berarti dalam meningkatkan hasil belajar IPA itu sendiri, dengan demikian untuk mencapai hasil belajar yang maksimal maka kedua variabel tersebut yaitu model pembelajaran dan tingkat kreativitas siswa perlu dipertimbangkan oleh guru.

Hasil penelitian ini berimplikasi terhadap Kepala Sekolah SDN 060856 Medan, beserta guruguru mata pelajaran IPA. Melihat perbaikan kemampuan siswa melalui 
model pembelajaran pemecahan masalah, sebaiknya yang berkompeten dengan pendidikan melakukan pelatihan atau semacam workshop tentang model pembelajaran terhadap guru dan bagaimana merancang, menyusun dan melaksanakan kegiatan pembelajaran sesuai dengan model pembelajaran yang dikembangkan. Dampak dari pelatihan ini mengakibatkan guruguru memiliki beberapa model pembelajaran yang diterapkan selama kegiatan belajar mengajar.

\section{DAFTAR RUJUKAN}

Abdurrahman, M. 2003. Pendidikan Anak Berkesulitan Belajar. Jakarta: Rineka Cipta.

Anderson, W.L., Sensibaugh, C.A., Osgood, M.P., \& Mitchell, S.M. 2011. What Really Matters: Assessing Individual ProblemSolving Performance in the Context of Biological Sciences. Georgia Southern University. International, Journal for the Scholarship of Teaching and Learning. 5(1): 1931-4744.

Arends, Richard I. 2008. Learning to Teach Belajar untuk Mengajar. (Edisi Ketujuh/ Buku Dua). Terjemahan Helly Pajitno Soetjipto \& Sri Mulyantini Soetjipto. Yogyakarta: Pustaka Pelajar

Arikunto, S. 2006. Prosedur Penelitian (Suatu Pendekatan
Praktik Edisi Revisi VI). Jakarta: Rineka Cipta.

Daryanto. 2009. Panduan Proses Pembelajaran Kreatif dan Inovatif. Jakarta: AV Publisher.

Djamarah, S.B. 2006. Stategi Belajar Mengajar. Rineka Cipta, Jakarta.

Dimyati. 2008. Belajar dan Pembelajaran. Jakarta: Rineka Cipta.

Hamalik, O. 2008. Kurikulum dan Pembelajaran. Jakarta: Bumi Aksara.

Munandar, U. 2009. Pengembangan Kreativitas Anak Berbakat. Jakarta: Rineka Cipta.

Rosmalinda, Desy, dkk. 2013. Pengembangan Modul Praktikum IPA SD Berbasis PBL (Problem Based Learning,. Jurnal) EduSains Volume 2 No. 2 Juli 2013.

Rusmono. 2012. Model-Model Pembelajaran. Jakarta: Raja Grafindo Persada.

Shadiq, F. 2004. Pemecahan Masalah, Penalaran, dan Komunikasi.http://fadjarp3g.word press.com/2007/10/09/whatresearch-says-aboutmathematical-problem-solving (diakses 12 Desember 2016).

Sipayung, V. N. 2011. Pengaruh Kreativitas dalm Pembelajaran Kontekstual Terhadap Hasil Belajar Siswa SMA, Tesis. 
Medan: Program Pascasarjana Unimed.

Slavin, R, E. 2008. Cooperative Learning: Teori, Riset, dan Praktik, Terjemahan Nurulita Yusron. Bandung: Nusa Media.

Sudjana, N., dan Rivai A. 2002. Media Pengajaran. Bandung: Sinar Baru Algensindo.

Suherman, E., \& Winataputra, U. 2001. Common TexBook Strategi Pembelajaran Matematika Kontemporer. Bandung: Jurusan Pendidikan Matematika UPI Bandung.

Tang, O.S. 2009. Problem Based Learning and Creativity. Singapore: Cengage Learning.

Trianto. 2011. Mendesain Model Pembelajaran Inovatif Progesif. Jakarta: Kencana.

Williamson, V, M. 2002. Group Problem Solving Versus Lecture in College-Level Quantitative Anakysis: The Good, The Bad, and The Ugly. Journal of Chemical Education. 79(9): 1131-1134. 